\title{
HAK JAMINAN ATAS RESI GUDANG DALAM PERSPEKTIF HUKUM JAMINAN
}

\author{
Trisadini Prasastinah Usanti \\ Fakultas Hukum Universitas Airlangga Surabaya \\ e-mail: aditris@ymail.com
}

\begin{abstract}
ABSTRAK
Undang-Undang Resi Gudang telah menciptakan lembaga jaminan baru, yaitu Hak Jaminan atas Resi Gudang. Hak Jaminan atas Resi Gudang belum menampakkan karakter dari lembaga jaminan kebendaan yang utuh sebagaimana lembaga jaminan kebendaan, karena tidak adanya asas droit de suite dan penentuan lahirnya hak kebendaan, sehingga ditafsirkan bahwa lahirnya hak kebendaan, yaitu pada saat kreditor memberitahukan kepada Pusat Registrasi dan pengelola gudang. Lahirnya hak kebendaan pada jaminan kebendaan merupakan hal yang sangat penting karena untuk menjamin kepastian hukum atas kedudukan kreditor sebagai kreditor preferen.

Kata Kunci: hak jaminan atas Resi Gudang, lembaga jaminan, hak kebendaan.

\section{ABSTRACT}

The Warehouse Receipt Act has created a new guarantee institution, namely The Rights Guarantee of Receipt Warehouse. The Rights Guarantee of Receipt Warehouse has not yet revealed the character of property security institution fully as property security institution, because the absence of droit de suite principle and the determination of the property right, so that it is interpreted that the outward of the property right, is when the creditor notified The Registration Center and warehouse manager. The outward of property right in the property guarantee is a very important thing to ensure legal certainty over the position of creditor as prefered creditor.
\end{abstract}

Keywords: the rights guarantee of receipt warehouse, security institution, property rights.

\section{PENDAHULUAN}

Pada kredit bank keberadaan jaminan dipandang penting meskipun tidak dapat dikatakan mutlak. Pada Undang-Undang Nomor 7 Tahun 1992 tentang Perbankan sebagaimana telah diubah dengan UndangUndang Nomor 10 Tahun 1998 (yang selanjutnya disebut Undang-Undang Perbankan) memberikan makna yang berbeda antara jaminan dengan agunan. Makna jaminan pemberian kredit adalah keyakinan bank atas kemampuan dan kesanggupan nasabah debitur untuk melunasi kewajibannya sesuai dengan yang diperjanjikan. Untuk memperoleh keyakinan tersebut, sebelum memberikan kredit, bank harus melakukan penilaian yang seksama terhadap watak, kemampuan, modal, agunan, dan prospek usaha dari debitur. Sedangkan makna agunan adalah jaminan tambahan yang diserahkan Nasabah Debitur kepada bank dalam rangka pemberian fasilitas kredit atau pembiayaan berdasarkan Prinsip Syariah. Agunan menjadi salah satu unsur jaminan pemberian kredit, berdasarkan Pasal 8 Undang-Undang Perbankan ada 2 (dua) jenis agunan yaitu, agunan pokok dan agunan tambahan. Agunan pokok adalah barang, proyek, atau hak tagih yang dibiayai dengan kredit yang bersangkutan. Sedangkan agunan tambahan adalah benda yang tidak berkaitan langsung dengan objek yang dibiayai kredit.

Sebagaimana diketahui makna jaminan selama ini dikenal adalah benda tertentu yang memiliki nilai ekonomis yang dipergunakan sebagai sumber pelunasan kredit apabila debitur wanprestasi. Dalam Black's Law Dictionary (Bryan A. Garner, 2004:1314) menyebutkan arti jaminan (security) adalah The term is usualy applied to an obligation, pledge, mortgage, deposit, lien, etc. Given by a debtor in order to make sure the payment or performance of his debt, by furnishing the creeditor with a resource to be used 
in case of failure in the principal obligation. The name is also sometimes given to one who becomes surety or guarantor for another.

Keberadaan jaminan merupakan upaya prefentif bagi bank dalam mengamankan utang debitur yang telah diberikan oleh bank, yaitu dengan cara menjaminkan kekayaan debitur agar debitur memenuhi kewajiban membayar kembali atau dengan adanya kesanggupan pihak ketiga untuk memenuhi prestasi debitur. Benda yang dapat dijadikan sebagai objek jaminan adalah berupa benda yang memenuhi syarat, yaitu memiliki nilai ekonomis dan dapat dipindahtangankan. Jenis jaminan kredit menurut BW dibedakan:

Pertama, Jaminan lahir karena undang-undang adalah jaminan yang keberadaannya karena ditentukan oleh undang-undang tidak perlu diperjanjikan antara kreditor dan debitur. Jaminan yang lahir karena undangundang merupakan jaminan umum sebagaimana diatur dalam Pasal 1131 BW bahwa segala kebendaan si berutang baik yang bergerak maupun yang tidak bergerak baik yang sudah ada maupun yang baru akan ada dikemudian hari menjadi tanggungan untuk segala perikatan perseorangan.

Kedua, Jaminan lahir karena diperjanjikan adalah keberadaannya karena diperjanjikan terlebih dahulu antara kreditor dan debitur. Jaminan yang lahir karena perjanjian merupakan jaminan khusus dapat berupa jaminan perorangan (Borgtocht/Personal Guarantee) yang diatur dalam Pasal 1820-1850 BW dan jaminan kebendaan, yaitu ada benda tertentu yang disediakan oleh debitur atau pihak ketiga sebagai jaminan.

Jaminan adalah sarana perlindungan bagi kreditor, yaitu kepastian akan pelunasan utang debitur atau pelaksanaan suatu prestasi oleh debitur atau oleh penjamin debitur. Undang-undang dalam hal ini telah memberikan sarana perlindungan bagi kreditor sebagaimana diatur pada Pasal 1131 BW dan Pasal 1132 BW.

Pasal 1131 BW menyatakan bahwa segala kebendaan si berhutang, baik yang bergerak maupun yang tak bergerak, baik yang sudah ada maupun yang baru akan ada di kemudian hari, menjadi tanggungan untuk segala perikatan perseorangan. Pasal 1132 BW menyatakan kebendaan menjadi jaminan bersama bagi semua orang yang mengutangkan padanya pendapatan penjualan benda itu dibagi-bagi menurut keseimbangan, yaitu menurut besar-kecilnya piutang masing-masing, kecuali apabila di antara para berpiutang itu ada alasanalasan yang sah untuk didahulukan.
Ketentuan Pasal 1131 BW ini merupakan jaminan secara umum yang lahir karena undang-undang. Undangundang memberikan perlindungan bagi semua kreditor dalam kedudukan yang sama, atau disini berlaku asas paritas creditorum, yaitu pembayaran atau pelunasan hutang kepada kreditor dilakukan secara berimbang (ponds-ponds gewijs). Dengan demikian para kreditor hanya berkedudukan sebagai kreditor konkuren yang bersaing dalam pemenuhan piutangnya, kecuali apabila ada alasan yang memberikan kedudukan preferen (droit de preference) kepada para kreditor tersebut (Sri Soedewi Masjchun Sofwan, 1981:32).

Kelemahan dari jaminan umum di samping kreditor berkedudukan sebagai kreditor konkuren, hak yang dilahirkan adalah hak perorangan yang bersifat pribadi, kreditor tidak mengetahui secara pasti berapa banyak dan berapa nilai dari seluruh harta kekayaan dari debitur, kreditor juga tidak mengetahui secara pasti berapa banyak kreditor yang dimiliki oleh debitur (Trisadini Prasastinah Usanti dan Leonora Bakarbessy, 2013:7). Disamping itu dengan tidak adanya benda tertentu untuk pelunasan utang kreditor maka bilamana dari hasil lelang tidak mencukupi baik karena jumlah pinjaman yang lebih besar atau karena banyaknya kreditor yang memperebutkan hasil lelang maka jelas kondisi ini merugikan kreditor karena dana yang telah dipinjamkan tidak kembali utuh.

Menyadari kelemahan dari jaminan umum yang ada dalam Pasal 1131 BW tersebut, maka pembentuk undang-undang menyiapkan pula alternatif perangkat jaminan lainnya yang lebih mantap yakni jaminan khusus yang objeknya juga benda milik debitur hanya saja sudah ditunjuk secara tertentu dan diperuntukkan bagi kreditor tertentu pula. Jaminan secara khusus adalah jaminan yang timbul dari perjanjian baik berupa perjanjian jaminan kebendaan maupun perorangan. Perjanjian jaminan adalah jaminan yang timbul karena adanya perjanjian pokok. Perjanjian jaminan merupakan perjanjian asesoir (accessoir), yaitu perjanjian yang melekat pada perjanjian pokok atau juga dikatakan perjanjian tambahan. Perjanjian jaminan bukan merupakan perjanjian yang berdiri sendiri tetapi bergantung pada perjanjian pokoknya.

Perjanjian jaminan kebendaan selalu merupakan perbuatan memisahkan suatu bagian dari kekayaan seseorang yang bertujuan untuk menjaminkan dan menyediakannya bagi pemenuhan kewajiban seorang debitur. Jaminan kebendaan merupakan hak mutlak (absolut) atas suatu benda tertentu yang menjadi 
objek jaminan suatu utang, yang suatu waktu dapat diuangkan bagi pelunasan utang debitur apabila debitur wanprestasi. Kekayaan tersebut dapat merupakan kekayaan debitur sendiri atau kekayaan orang ketiga (Djuhaendah Hasan, 2000:18). Jenis-jenis pengikatan jaminan kebendaan, yaitu: Hak Tanggungan, yang diatur dalam Undang-Undang Nomor 4 Tahun 1996 tentang Hak Tanggungan atas Tanah Beserta Bendabenda yang Berkaitan dengan Tanah (yang selanjutnya disebut UUHT); Hipotik, diatur dalam Pasal 1162-1232 BW; Gadai (Pand), diatur dalam Pasal 1150-1160 BW; Jaminan Fidusia, diatur dalam Undang-Undang Nomor 42 Tahun 1999 tentang Jaminan Fidusia (yang selanjutnya disebut UUJF).

Akan tetapi, pada tahun 2006 dengan lahirnya Undang-Undang Nomor 9 Tahun 2006 tentang Resi Gudang sebagaimana telah diubah dengan UndangUndang Nomor 9 Tahun 2011, selanjutnya disingkat dengan UU Resi Gudang, mendeklarasikan munculnya lembaga jaminan baru, yaitu "Hak Jaminan Resi Gudang". Sebagaimana ditegaskan pada penjelasan Pasal 12 ayat (1) bahwa Lembaga jaminan telah diatur dalam Undang-Undang Nomor 4 Tahun 1996 tentang Hak Tanggungan yang merupakan pelaksanaan Pasal 51 Undang-Undang Pokok Agraria dan sekaligus sebagai pengganti Lembaga Hipotek atas tanah dan creditverband. Di samping itu, hak jaminan lainnya yang banyak digunakan dewasa ini adalah Gadai, Hipotek selain tanah dan jaminan Fidusia. Namun, dari berbagai ketentuan jaminan tersebut, dan dengan memperhatikan sifatnya, Resi Gudang tidak dapat dijadikan objek yang dapat dibebani oleh satu di antara bentuk jaminan tersebut.

Undang-undang ini dimaksudkan menampung kebutuhan Pemegang Resi Gudang atas ketersediaan dana melalui lembaga jaminan tanpa harus mengubah bangunan hukum mengenai lembaga-lembaga jaminan yang sudah ada. Dengan demikian, undang-undang ini menciptakan lembaga hukum jaminan tersendiri di luar lembaga-lembaga jaminan yang telah ada yang disebut Hak Jaminan atas Resi Gudang sebagai salah satu sarana membantu kegiatan usaha dan memberikan kepastian hukum kepada para pihak yang berkepentingan. Demikian halnya keberadaan hak jaminan atas Resi Gudang juga diakui sebagai lembaga jaminan baru pada Peraturan Bank Indonesia Nomor 14/5/PBI/2012 tentang Penilaian Kualitas Aset Bank Umum, sebagaimana tertuang dalam Pasal 43, bahwa agunan yang dapat diperhitungkan sebagai pengurang dalam perhitungan PPA ditetapkan sebagai berikut: Pertama, Surat Berharga dan saham yang aktif diperdagangkan di bursa efek di Indonesia atau memiliki peringkat investasi dan diikat secara Gadai; Kedua, Tanah, gedung, dan rumah tinggal yang diikat dengan hak tanggungan; Ketiga, Mesin yang merupakan satu kesatuan dengan tanah yang diikat dengan hak tanggungan; Keempat, Pesawat udara atau kapal laut dengan ukuran di atas 20 (dua puluh) meter kubik yang diikat dengan Hipotek; Kelima, Kendaraan bermotor dan persediaan yang diikat secara Fidusia; dan/atau Keenam, Resi Gudang yang diikat dengan hak jaminan atas Resi Gudang.

Dari uraian pendahuluan di atas, masalah yang hendak dikaji dirumuskan, yaitu eksistensi hak jaminan atas Resi Gudang dalam perspektif hukum jaminan.

\section{PEMBAHASAN \\ Karakter Resi Gudang}

Berdasarkan Pasal 1 angka 2 UU Resi Gudang yang dimaksud dengan Resi Gudang adalah dokumen bukti kepemilikan atas barang yang disimpan di Gudang yang diterbitkan oleh Pengelola Gudang. Resi Gudang adalah surat berharga yang mewakili barang yang disimpan di Gudang. Sebagai surat berharga, Resi Gudang juga dapat dialihkan atau diperjualbelikan di pasar yang terorganisasi (bursa) atau di luar bursa oleh Pemegang Resi Gudang kepada pihak ketiga. Dengan terjadinya pengalihan Resi Gudang tersebut, kepada Pemegang Resi Gudang yang baru diberikan hak untuk mengambil barang yang tercantum di dalamnya.

Pada Pasal 3 UU Resi Gudang disebutkan bahwa ada 2 (dua) Jenis Resi Gudang, yaitu Resi Gudang dengan warkat adalah surat berharga yang kepemilikannya berupa sertifikat baik atas nama maupun atas perintah, sedangkan Resi Gudang tanpa warkat (scripless) adalah surat berharga yang kepemilikannya dicatat secara elektronis. Dalam hal Resi Gudang tanpa warkat, bukti kepemilikan yang autentik dan sah adalah pencatatan kepemilikan secara elektronis. Cara pencatatan secara elektronis dimaksudkan agar pengadministrasian data kepemilikan dan penyelesaian transaksi perdagangan Resi Gudang tanpa warkat dapat diselenggarakan secara efisien, cepat, aman, transparan, dan dapat dipertanggungjawabkan.

Resi Gudang harus memuat sekurang-kurangnya: judul Resi Gudang; jenis Resi Gudang; nama dan alamat pihak pemilik barang; lokasi gudang tempat penyimpanan barang; tanggal penerbitan; nomor 
penerbitan; waktu jatuh tempo simpan barang; deskripsi barang; biaya penyimpanan dan tanda tangan pemilik barang dan Pengelola Gudang. Resi Gudang dapat dialihkan, dijadikan jaminan utang, atau digunakan sebagai dokumen penyerahan barang. Apabila Resi Gudang dijadikan jaminan utang maka Resi Gudang sepenuhnya menjadi agunan pokok tanpa dipersyaratkan adanya agunan lainnya.

Barang yang dapat disimpan di gudang untuk diterbitkan Resi Gudang paling sedikit memenuhi persyaratan sebagai berikut: memiliki daya simpan paling sedikit 3 (tiga) bulan; memenuhi standar mutu tertentu; dan jumlah minimum barang yang dapat disimpan.

Berdasarkan Peraturan Menteri Perdagangan RI Nomor 26/M-DAG/PER/6/2007 tentang barang yang dapat disimpan di gudang dalam penyelenggaraan Sistem Resi Gudang, yaitu berupa gabah, beras, jagung, kopi, kakao, lada, karet dan rumput laut. Penetapan selanjutnya tentang Barang dalam rangka Sistem Resi Gudang dilakukan dengan mempertimbangkan rekomendasi dari pemerintah daerah, instansi terkait, atau asosiasi komoditas dengan tetap memperhatikan persyaratan sebagaimana dimaksud di atas.

Kegiatan Pusat Registrasi dapat dilakukan oleh lembaga kliring berjangka yang dibentuk berdasarkan Undang-Undang Nomor 32 Tahun 1997 tentang Perdagangan Berjangka Komoditi atau badan usaha lain yang khusus dibentuk untuk itu dan memenuhi persyaratan yang telah ditetapkan oleh pemerintah. Penatausahaan oleh Pusat Registrasi mempunyai tujuan agar peredaran, pengalihan, serta penjaminan Resi Gudang dan Derivatif Resi Gudang baik yang warkat maupun tanpa warkat dapat dipantau oleh Pusat Registrasi sehingga memberikan kepastian hukum bagi Pemegang Resi Gudang dan kreditor.

Sedangkan karakter Barang menurut UU Resi Gudang adalah setiap benda bergerak yang dapat disimpan dalam jangka waktu tertentu dan diperdagangkan secara umum. Berarti tidak setiap barang dapat disimpan di gudang karena ada batasan disimpan dalam jangka waktu tertentu dan sebagai objek perdagangan umum, seperti tembakau, kopi. Kegiatan yang berkaitan dengan penerbitan, pengalihan, penjaminan, dan penyelesaian transaksi Resi Gudang termasuk dalam Sistem Resi Gudang.

Resi Gudang dibebani dengan hak jaminan atas Resi Gudang untuk selanjutnya disebut hak jaminan. Bentuk perjanjian penjaminan Resi Gudang berdasarkan Pasal 14 UU Resi Gudang dibuat dalam Akta Perjanjian Hak Jaminan. Adapun tujuannya adalah untuk melindungi dan memberikan kekuatan hukum bagi para pihak dan dapat digunakan sebagai alat bukti yang sempurna dalam penyelesaian sengketa. Makna dari kata "Akta Perjanjian Hak Jaminan" mempunyai 2 (dua) arti, yaitu dapat diartikan bahwa akta perjanjian hak jaminan dalam bentuk akta di bawah tangan dan dalam bentuk akta otentik. Akan tetapi, jika mengacu pada penjelasan Pasal 14 UU Resi Gudang terdapat kata-kata "... sebagai alat bukti yang sempurna ..." maka dapat diartikan bahwa perjanjian hak jaminan atas Resi Gudang dalam bentuk otentik sebagaimana diatur pada Pasal 1868 BW bahwa akta otentik adalah akta yang di dalam bentuk yang ditentukan oleh undangundang, dibuat oleh atau dihadapan pegawai-pegawai umum yang berkuasa untuk itu di tempat dimana akta dibuatnya. Pejabat yang berwenang untuk membuat akta otentik, yaitu notaris.

Berdasarkan lampiran Peraturan Kepala Badan Pengawasan Perdagangan Berjangka Komoditi Nomor 09/BAPPEBTI/PER-SRG/7/2008 tentang Pedoman Tehnis Penjaminan Resi Gudang tanggal 24 Juli 2008, ditentukan model Formulir Nomor SRG-OPR 14 tentang Perjanjian Pembebanan Hak Jaminan Atas Resi Gudang yang berisikan tentang identitas para pihak, yaitu pemberi dan penerima hak jaminan, data perjanjian pokok yang dijamin dengan hak jaminan, spesifikasi Resi Gudang yang diagunkan, nilai jaminan utang dan nilai barang berdasarkan harga pasar pada saat barang dimasukkan ke dalam gudang. Disamping itu dalam perjanjian tersebut memuat ketentuan sebagai berikut:

Pertama, Resi Gudang berada dalam kekuasaan pihak kedua dalam hal ini adalah bank penerima hak jaminan.

Kedua, Bank berkewajiban untuk memastikan keabsahan dan kelengkapan Resi Gudang sebagai objek yang akan dibebani Hak Jaminan dengan meminta Pusat Registrasi untuk melakukan verifikasi.

Ketiga, Atas pembebanan Hak Jaminan tersebut bank wajib memberitahukan kepada Pusat Registrasi dan Pusat Registrasi setelah melakukan verifikasi dengan hasil sesuai persyaratan, menerbitkan konfirmasi bahwa Pembebanan Hak Jaminan tersebut telah ditatausahakan pada Pusat Registrasi paling lambat 1 (satu) hari setelah tanggal perjanjian ini.

Keempat, Dalam hal debitur lalai membayar hutangnya maka bank berhak mencairkan atau 
menjual Resi Gudang dengan tata cara sebagaimana diatur dalam peraturan perundang-undangan dan bank berhak mengambil hasil penjualan Resi Gudang tersebut sebagai pembayaran atas seluruh hutang debitur kepada bank.

Kelima, Apabila hasil dari pencairan atau penjualan atas Resi Gudang lebih besar dari jumlah Fasilitas kredit yang diterima oleh debitur, ditambah dengan biaya bunga dan biaya administrasi dan/atau biaya pencairan agunan, maka yang dapat diambil oleh bank adalah sebesar jumlah dimaksud, sedang kelebihannya harus dikembalikan oleh bank kepada debitur sebagai pemiliknya.

Setelah dibuat perjanjian pembebanan hak jaminan atas Resi Gudang maka paling lambat 1 (satu) hari setelah tanggal perjanjian pembebanan hak jaminan atas Resi Gudang, bank sebagai pihak penerima hak jaminan wajib memberitahukan kepada Pusat Registrasi Sistem Resi Gudang agar dilakukan pencatatan pada Buku Daftar Pembebanan Hak Jaminan atas Resi Gudang. Kemudian pihak Pusat Registrasi akan mengeluarkan Bukti Konfirmasi pemberitahuan pembebanan Hak Jaminan bahwa telah diterima dan telah dilakukan pencatatan. Hal ini dilakukan agar tidak terjadi penjaminan ganda serta memantau peredaran Resi Gudang dan memberikan kepastian hukum tentang pihak yang berhak atas barang dalam hal terjadi cedera janji.

\section{Ciri Hak Kebendaan Pada Hak Jaminan}

Arti perjanjian kebendaan adalah suatu perjanjian yang dibuat oleh para pihak untuk melahirkan, mengubah, atau meniadakan hak kebendaan. Kalau hak kebendaan yang dimaksud telah lahir, maka perjanjian tersebut berakhir sudah. Lagi pula dari perjanjian jaminan kebendaan ini mengakibatkan munculnya hak kebendaan yang bersifat mutlak, dalam arti dapat ditegakkan terhadap siapapun. Pemegang jaminan kebendaan memiliki hak kebendaan dengan ciri-ciri yang sangat istimewa. Adapun ciri pokok dari hak kebendaan itu adalah hak kebendaan bersifat mutlak, ada "droit de suite", ada preferensi, mengandung asas prioritas (M. Isnaeni, 1996:46). Hak kebendaan itu bersifat mutlak dengan pengertian bahwa hak itu dapat ditegakkan terhadap siapa pun, tidak sekedar pada rekan sekontrak saja, tetapi juga kepada pihak-pihak lain yang mungkin di kemudian hari ikut terkait. Hal ini berbeda dengan hak perorangan atau hak relatif yang hanya bisa ditegakkan pada pihak tertentu saja, yakni rekan sekontrak. Hak kebendaan itu mempunyai zaakgevolg atau droit de suite artinya hak itu akan tetap mengikuti bendanya ke tangan siapa pun benda itu berada. Jadi hak kebendaan itu melekat pada bendanya, sehingga kalau berpindah tangan, yang bersangkutan akan terkena pula untuk wajib menghormatinya. Hak kebendaan mempunyai droit de preference (hak terlebih dahulu) bahwa pihak yang memiliki hak kebendaan ini didahulukan dalam hal pembayaran daripada kreditor lainnya. Selain itu hak kebendaan mengandung asas prioritas artinya hak kebendaan yang lahir terlebih dahulu akan diutamakan dibandingkan dengan yang lahir kemudian (M. Isnaeni, 1996:47).

Demikian juga dikemukakan oleh Mariam Darus Badrulzaman (2010:36) dalam membagi asas-asas dalam hak kebendaan sebagai berikut:

Pertama, Asas sistem tertutup. Hak kebendaan mempunyai sistem tertutup. Maksudnya ialah bahwa hak-hak atas benda bersifat limitatif, terbatas hanya pada yang diatur undang-undang. Di luar itu, dengan perjanjian tidak diperkenankan menciptakan hak-hak baru.

Kedua, Asas hak mengikuti benda (zaaksgevolg, droit de suite). Asas ini mengatakan bahwa hak kebendaan mengikuti bendanya dimana saja dan dalam tangan siapa pun benda tersebut berada.

Ketiga, Asas publisitas. Dimaksud dengan publisitas (openbaarheid) adalah "pengumuman" kepada masyarakat mengenai status pemilikan. Pengumuman hak atas benda tetap (tanah) terjadi melalui pendaftaran dalam buku tanah, sedangkan pengumuman benda bergerak melalui penguasaan nyata benda itu.

Keempat, Asas spesialitas. Dalam lembaga hak kepemilikan atas tanah secara individual harus ditunjukkan dengan jelas wujud, batas, letak, luas tanah. Asas ini terdapat pada hak (milik, guna usaha, guna bangunan) atas benda tetap.

Kelima, Asas totalitas. Hak kepemilikan hanya dapat diletakkan terhadap objeknya secara totalitas, dengan perkataan lain hak itu tidak dapat diletakkan hanya untuk bagian-bagian benda. Pemilik sebuah bangunan dengan sendirinya adalah pemilik kusen, jendela, pintu dan genteng rumah.

Keenam, Asas accessie. Asas totalitas ini muncul asas perlekatan (accessie). Suatu benda lazimnya terdiri dari bagian-bagian yang melekat menjadi satu dengan benda pokok, seperti hubungan antara bangunan dengan genteng, kusen, pintu, dan jendela. 
Ketujuh, Asas pemisahan horizontal. BW mengenal asas perlekatan vertikal dalam Pasal 571, 600, 601, 603, 604 dan 605. UUPA tidak menganut asas perlekatan saja, akan tetapi menganut pemisahan horizontal yang diambil dari asas hukum adat. Dalam Pasal 4 ayat (4) UUHT asas yang berlaku adalah asas pemisahan horizontal tetapi tidak bersifat mutlak dikarenakan Hak Tanggungan dapat juga dibebankan pada hak atas tanah berikut bangunan, tanaman dan hasil karya yang telah ada atau akan ada yang merupakan satu kesatuan dengan tanah tersebut, dan yang merupakan milik pemegang hak atas tanah yang pembebanannya dengan tegas dinyatakan dalam Akta Pemberian Hak Tanggungan (Trisadini Prasastinah Usanti, 2012:46).

Kedelapan, Asas dapat diserahkan, yaitu Hak kepemilikan mengandung wewenang untuk menyerahkan benda.

Kesembilan, Asas perlindungan. Perlindungan bagi pihak yang beritikad baik walaupun yang menyerahkan adalah pihak yang tidak berwenang berhak (beschikkings on bevoegd), sebagaimana diatur pada Pasal 1977 ayat (1) BW.

Kesepuluh, Asas absolut (hukum pemaksa). Ketentuan-ketentuan yang mengatur hukum benda bersifat absolut artinya bahwa hak kebendaan wajib dihormati dan ditaati oleh setiap orang.

Menurut Mariam Darus Badrulzaman bahwa lembaga pendaftaran tidak semata-mata mengandung arti untuk memberikan alat bukti yang kuat, akan tetapi juga menciptakan hak kebendaan. Hak kebendaan atas suatu benda (tanah) terjadi pada saat pendaftaran dilakukan. Tanpa sifat kebendaan hak atas tanah belum mempunyai kaitan dengan "milik". Dalam arti selama pendaftaran belum dilakukan hak hanya mempunyai arti terhadap para pihak pribadi dan umum belum mengetahui perubahan status hukum dari benda. Pengakuan masyarakat baru terjadi pada saat milik atas benda tersebut didaftarkan. Melalui pendaftaran lahirlah pengakuan umum terhadap hubungan hak dengan benda (Mariam Darus Badrulzaman, 2010: 37). Berikut diuraikan perbandingan antara lembaga jaminan Gadai, Hipotek, hak tanggungan, Fidusia dengan hak jaminan atas Resi Gudang.

Berdasarkan tabel 1 maka dapat dirangkum bahwa karakteristik suatu lembaga jaminan apabila dikatakan sebagai lembaga jaminan kebendaan maka terdapat ciri-ciri dari jaminan kebendaan, yaitu terdapat asas-asas hak kebendaan sebagaimana diuraikan sebelumnya. Sedangkan pada hak jaminan ciri-ciri yang seharusnya ada pada lembaga jaminan ternyata tidak terdapat dalam UU Resi Gudang, yaitu tidak adanya asas droit de suite. Sebagaimana diketahui keberadaan asas droit de suite merupakan salahsatu ciri dari hak kebendaan yang membedakan dengan hak perorangan (hak pribadi). Asas droit de suite pada UU Resi Gudang dapat ditafsirkan akan lahir apabila hak kebendaan pada hak jaminannya lahir. Sebagai contoh, hak tanggungan lahir pada saat didaftarkan ke kantor pertanahan sebagaimana diatur pada Pasal 13 ayat (5) UUHT, sehingga dengan lahirnya hak tanggungan sebagai hak kebendaan maka otomatis ciri-ciri hak kebendaan akan melekat pada kreditor penerima hak tanggungan, meskipun asas droit de suite tersurat secara tegas dalam Pasal 7 UUHT.

Pada hak jaminan tidak mengatur secara tegas kapan lahirnya hak kebendaan pada hak jaminan sebagaimana pada lembaga jaminan hak tanggungan dan Fidusia, sehingga lahirnya hak kebendaan dapat dikaji dari isi Pasal 13 ayat (2) UU Resi Gudang yang menyebutkan bahwa Penerima Hak Jaminan harus memberitahukan perjanjian pengikatan Resi Gudang sebagai Hak jaminan kepada Pusat Registrasi dan Pengelola Gudang. Pada penjelasannya disebutkan bahwa pemberitahuan ini memuat pula data perjanjian pokok utang piutang yang mendasari timbulnya jaminan. Pemberitahuan tersebut akan mempermudah Pusat Registrasi dan Pengelola Gudang dalam rangka mencegah adanya penjaminan ganda serta memantau peredaran Resi Gudang dan memberikan kepastian hukum tentang pihak yang berhak atas barang dalam hal terjadi cedera janji.

Makna kata "memberitahukan" perjanjian pengikatan Resi Gudang pada Pusat Registrasi dan Pengelola Gudang, apakah mempunyai makna sama dengan kata pendaftaran pada lembaga jaminan Hipotek, hak tanggungan maupun jaminan Fidusia. Pendaftaran merupakan perwujudan dari asas publisitas yang menandai lahirnya hak kebendaan. Sebagaimana diketahui bahwa pada lembaga jaminan Hipotek, hak tanggungan dan Fidusia ada instansi khusus berdasarkan undang-undang yang berwenang untuk melakukan pendaftaran jaminan tersebut seperti kantor pertanahan yang berwenang untuk melakukan pendaftaran hak tanggungan dan menerbitkan sertifikat hak tanggungan yang memuat irah-irah dengan kata "Demi Keadilan Berdasarkan Ketuhanan Yang Maha Esa”. Sedangkan Pusat Registrasi berdasarkan Pasal 1 angka 13 UU 
Tabel 1 Perbandingan antara Lembaga Jaminan Gadai, Hipotek, Hak Tanggungan, Fidusia, dan Hak Jaminan atas Resi Gudang

\begin{tabular}{|c|c|c|c|c|c|}
\hline Karakter & Gadai & Hipotek & Hak Tanggungan & Fidusia & $\begin{array}{c}\text { Hak Jaminan atas Resi Gudang } \\
\text { (Hak Jaminan) }\end{array}$ \\
\hline $\begin{array}{l}\text { Dasar } \\
\text { Hukum }\end{array}$ & $\begin{array}{l}\text { Pasal 1150-1160 } \\
\text { BW }\end{array}$ & $\begin{array}{l}\text { Pasal 1161-1232 } \\
\text { BW }\end{array}$ & $\begin{array}{l}\text { Undang-Undang } \\
\text { Nomor } 4 \text { Tahun } \\
1996\end{array}$ & $\begin{array}{l}\text { Undang-Undang } \\
\text { Nomor } 42 \text { Tahun } \\
1999\end{array}$ & $\begin{array}{l}\text { Undang-Undang Nomor } 9 \\
\text { Tahun } 2011 \text { tentang Perubahan } \\
\text { Undang-Undang Nomor } 9 \\
\text { Tahun } 2006 \text { (UU Resi Gudang) } \\
\text { dan PP Nomor } 36 \text { Tahun } 2007\end{array}$ \\
\hline $\begin{array}{l}\text { Bentuk } \\
\text { Perjanjian }\end{array}$ & $\begin{array}{l}\text { Pasal } 1151 \mathrm{BW}, \\
\text { dalam bentuk } \\
\text { tertulis }\end{array}$ & $\begin{array}{l}\text { Pasal } 1171 \mathrm{BW}, \\
\text { akta otentik }\end{array}$ & $\begin{array}{l}\text { Akta PPAT, } \\
\text { Pasal } 10 \text { ayat }(2) \\
\text { UUHT }\end{array}$ & $\begin{array}{l}\text { Akta otentik, } \\
\text { Pasal } 5 \text { ayat }(1) \\
\text { UUJF }\end{array}$ & $\begin{array}{l}\text { Dibuat akta perjanjian hak } \\
\text { jaminan (Pasal } 14 \text { ayat (1) UU } \\
\text { Resi Gudang. }\end{array}$ \\
\hline Objek & $\begin{array}{l}\text { Benda bergerak } \\
\text { baik yang } \\
\text { berwujud maupun } \\
\text { tidak berwujud }\end{array}$ & $\begin{array}{l}\text { Benda tidak } \\
\text { bergerak, yaitu } \\
\text { kapal laut } \\
\text { dengan bobot } \\
20 \mathrm{~m}^{3} \text {. Undang- } \\
\text { Undang Nomor } \\
\text { dan Pasal } 314 \\
\text { KUHD }\end{array}$ & $\begin{array}{l}\text { Hak atas tanah } \\
\text { beserta benda- } \\
\text { benda yang } \\
\text { berkaitan dengan } \\
\text { tanah }\end{array}$ & $\begin{array}{l}\text { Benda bergerak } \\
\text { baik yang } \\
\text { berwujud } \\
\text { maupun yang } \\
\text { tidak berwujud } \\
\text { dan benda } \\
\text { bergerak } \\
\text { khususnya } \\
\text { bangunan yang } \\
\text { tidak dapat } \\
\text { dibebani hak } \\
\text { tanggungan }\end{array}$ & $\begin{array}{l}\text { Resi Gudang sebagai dokumen } \\
\text { kepemilikan atas barang yang } \\
\text { disimpan di Gudang yang } \\
\text { diterbitkan oleh Pengelola } \\
\text { Gudang. } \\
\text { (Pasal } 1 \text { angka } 2 \text { jo. Pasal } 4 \\
\text { ayat (2) UU Resi Gudang) }\end{array}$ \\
\hline $\begin{array}{l}\text { Penguasaan } \\
\text { Objek } \\
\text { Jaminan }\end{array}$ & $\begin{array}{l}\text { Pada Kreditor } \\
\text { atau pihak ketiga } \\
\text { (Pasal } 1152(2) \\
\text { BW }\end{array}$ & $\begin{array}{l}\text { Pada pemilik } \\
\text { benda }\end{array}$ & $\begin{array}{l}\text { Pada pemilik } \\
\text { benda }\end{array}$ & $\begin{array}{l}\text { Pada pemilik } \\
\text { benda }\end{array}$ & $\begin{array}{l}\text { Resi Gudang wajib berada } \\
\text { dalam penguasaan kreditor, } \\
\text { Penjelasan Pasal } 12 \text { ayat (2) } \\
\text { UU Resi Gudang }\end{array}$ \\
\hline $\begin{array}{l}\text { Kewenangan } \\
\text { Menjaminkan }\end{array}$ & $\begin{array}{l}\text { Pasal } 1152 \text { (4) } \\
\text { BW: Hal tidak } \\
\text { adanya wewenang } \\
\text { pemberi Gadai } \\
\text { untuk bertindak } \\
\text { bebas atas barang } \\
\text { itu, tidak dapat } \\
\text { dipertanggung- } \\
\text { jawabkan kepada } \\
\text { kreditor, tanpa } \\
\text { mengurangi hak } \\
\text { orang yang telah } \\
\text { kehilangan } \\
\text { atau kecurigaan } \\
\text { barang itu untuk } \\
\text { menuntutnya } \\
\text { kembali. }\end{array}$ & $\begin{array}{l}\text { Pasal } 1168 \mathrm{BW} \text { : } \\
\text { Hipotek tidak } \\
\text { dapat diadakan } \\
\text { selain oleh } \\
\text { orang yang } \\
\text { mempunyai } \\
\text { wewenang untuk } \\
\text { memindah- } \\
\text { tangankan } \\
\text { barang yang } \\
\text { dibebani itu. }\end{array}$ & $\begin{array}{l}\text { Pasal } 8 \text { UUHT, } \\
\text { kewenangan } \\
\text { harus ada pada } \\
\text { saat pendaftaran } \\
\text { hak tanggungan } \\
\text { dilakukan }\end{array}$ & $\begin{array}{l}\text { Pasal } 1 \text { angka } \\
5 \text { UUJF, } \\
\text { pemberi Fidusia } \\
\text { adalah orang } \\
\text { perorangan } \\
\text { atau korporasi } \\
\text { pemilik benda } \\
\text { yang menjadi } \\
\text { objek jaminan } \\
\text { Fidusia }\end{array}$ & $\begin{array}{l}\text { Pasal } 1 \text { angka } 7 \text { UU Resi } \\
\text { Gudang disebutkan bahwa } \\
\text { Pemegang Resi Gudang adalah } \\
\text { pemilik barang atau pihak yang } \\
\text { menerima pengalihan dari } \\
\text { pemilik barang atau pihak lain } \\
\text { yang menerima pengalihan } \\
\text { lebih lanjut. }\end{array}$ \\
\hline $\begin{array}{l}\text { Asas droit de } \\
\text { suite }\end{array}$ & $\begin{array}{l}\text { Tersurat dalam } \\
\text { Pasal } 1152(3) \\
\text { BW }\end{array}$ & $\begin{array}{l}\text { Tersurat dalam } \\
\text { Pasal } 1163(2) \\
\text { BW }\end{array}$ & $\begin{array}{l}\text { Tersurat dalam } \\
\text { Pasal } 7 \text { UUHT }\end{array}$ & $\begin{array}{l}\text { Tersurat dalam } \\
\text { Pasal } 20 \text { UUJF }\end{array}$ & $\begin{array}{l}\text { Tidak ada pasal dalam UU } \\
\text { Resi Gudang yang merupakan } \\
\text { perwujudan dari asas droit de } \\
\text { suite }\end{array}$ \\
\hline $\begin{array}{l}\text { Asas droit de } \\
\text { preferens }\end{array}$ & $\begin{array}{l}\text { Pasal } 1133 \text { dan } \\
\text { Pasal } 1150 \text { BW }\end{array}$ & $\begin{array}{l}\text { Pasal } 1133 \text { dan } \\
\text { Pasal } 1198 \text { BW }\end{array}$ & $\begin{array}{l}\text { Pasal } 1 \text { angka } 1 \\
\text { UUHT }\end{array}$ & $\begin{array}{l}\text { Pasal } 1 \text { angka } 2 \\
\text { UUJF }\end{array}$ & $\begin{array}{l}\text { Pasal } 1 \text { angka } 9 \text { UU Resi } \\
\text { Gudang }\end{array}$ \\
\hline $\begin{array}{l}\text { Asas } \\
\text { Publisitas }\end{array}$ & $\begin{array}{l}\text { Pasal } 1152(1) \\
\text { BW }\end{array}$ & Pasal 1179 BW & $\begin{array}{l}\text { Pasal } 13 \text { ayat (1) } \\
\text { UUHT }\end{array}$ & $\begin{array}{l}\text { Pasal } 11 \text { ayat }(1) \\
\text { UUJF }\end{array}$ & $\begin{array}{l}\text { Pasal } 13 \text { UU Resi Gudang } \\
\text { mengatur bahwa Penerima Hak } \\
\text { Jaminan harus memberitahukan } \\
\text { perjanjian pengikatan Resi } \\
\text { Gudang sebagai Hak } \\
\text { Jaminan kepada Pusat } \\
\text { Registrasi dan Pengelola } \\
\text { Gudang }\end{array}$ \\
\hline
\end{tabular}




\section{Lanjutan Tabel 1}

\begin{tabular}{|c|c|c|c|c|c|}
\hline Karakter & Gadai & Hipotek & Hak Tanggungan & Fidusia & $\begin{array}{c}\text { Hak Jaminan atas Resi Gudang } \\
\text { (Hak Jaminan) }\end{array}$ \\
\hline $\begin{array}{l}\text { Asas } \\
\text { prioritas }\end{array}$ & $\begin{array}{l}\text { Tidak terdapat } \\
\text { dalam Gadai } \\
\text { karena tidak ada } \\
\text { Gadai ulang untuk } \\
\text { kreditor yang } \\
\text { berbeda }\end{array}$ & Pasal $1181 \mathrm{BW}$ & Pasal 5 UUHT & $\begin{array}{l}\text { Pasal } 28 \\
\text { UUJF dengan } \\
\text { memperhatikan } \\
\text { Pasal } 17 \text { UUJF }\end{array}$ & $\begin{array}{l}\text { Tidak terdapat karena pada } \\
\text { Pasal } 12 \text { ayat (2) UU Resi } \\
\text { Gudang menyebutkan bahwa } \\
\text { Resi Gudang hanya dapat } \\
\text { dibebani satu jaminan hutang } \\
\text { sehingga tidak dimungkinkan } \\
\text { dijaminkan pada kreditor yang } \\
\text { berbeda }\end{array}$ \\
\hline $\begin{array}{l}\text { Asas } \\
\text { spesialitas }\end{array}$ & $\begin{array}{l}\text { Tidak mengatur } \\
\text { secara khusus }\end{array}$ & Pasal 1174 BW & Pasal 11 UUHT & Pasal 6 UUFJ & Pasal 14 UU Resi Gudang \\
\hline $\begin{array}{l}\text { Lahirnya } \\
\text { Hak } \\
\text { Kebendaan }\end{array}$ & $\begin{array}{l}\text { Pada saat benda } \\
\text { diserahkan } \\
\text { kepada kreditor } \\
\text { atau pihak ketiga } \\
\text { (Inbezitstelling) } \\
\text { Pasal } 1152 \text { ayat } \\
\text { (1) BW }\end{array}$ & $\begin{array}{l}\text { Pada saat } \\
\text { didaftarkan } \\
\text { ke kantor } \\
\text { pendaftaran dan } \\
\text { pencatatan balik } \\
\text { nama kapal, } \\
\text { departemen } \\
\text { perhubungan } \\
\text { laut }\end{array}$ & $\begin{array}{l}\text { Pada saat } \\
\text { didaftarkan } \\
\text { ke kantor } \\
\text { pertanahan, } \\
\text { Pasal } 13 \text { ayat (5) } \\
\text { UUHT }\end{array}$ & $\begin{array}{l}\text { Pada saat } \\
\text { didaftarkan ke } \\
\text { kantor Hukum } \\
\text { dan HAM, Pasal } \\
14 \text { ayat (3) UUJF } \\
\text { dan berdasarkan } \\
\text { SE Dirjen AHU } \\
\text { No. AHU- } \\
\text { 06.OT.0301 } \\
\text { tahun } \\
\text { 2013, maka } \\
\text { pendaftaran } \\
\text { jaminan Fidusia } \\
\text { dilakukan secara } \\
\text { elektronik }\end{array}$ & $\begin{array}{l}\text { Apakah pada saat Penerima } \\
\text { Hak Jaminan memberitahukan } \\
\text { perjanjian pengikatan Resi } \\
\text { Gudang sebagai Hak } \\
\text { Jaminan kepada Pusat } \\
\text { Registrasi dan Pengelola } \\
\text { Gudang? }\end{array}$ \\
\hline $\begin{array}{l}\text { Eksekusi } \\
\text { objek } \\
\text { jaminan }\end{array}$ & $\begin{array}{l}\text { Parate eksekusi } \\
\text { Pasal } 1155 \mathrm{BW}, \\
\text { lahir karena UU }\end{array}$ & $\begin{array}{l}\text { Pasal } 1178 \text { BW, } \\
\text { parate eksekusi } \\
\text { lahir karena } \\
\text { diperjanjikan }\end{array}$ & $\begin{array}{l}\text { Pasal } 6 \text { jo Pasal } \\
20 \text { UUHT } \\
\text { terdapat } 3 \\
\text { macam eksekusi }\end{array}$ & $\begin{array}{l}\text { Pasal } 15 \text { jo } \\
\text { Pasal } 29 \text { UUJF, } \\
\text { terdapat } 3 \\
\text { macam eksekusi }\end{array}$ & $\begin{array}{l}\text { Parate eksekusi lahir karena } \\
\text { UU, Pasal } 16 \text { UU Resi Gudang }\end{array}$ \\
\hline
\end{tabular}

Resi Gudang adalah badan usaha berbadan hukum yang mendapat persetujuan Badan Pengawas untuk melakukan penatausahaan Resi Gudang dan Derivatif Resi Gudang yang meliputi pencatatan, penyimpanan, pemindahbukuan kepemilikan, pembebanan hak jaminan, pelaporan, serta penyediaan sistem dan jaringan informasi.

Pusat registrasi dalam kaitan pembebanan jaminan hanya bertugas melakukan penatausahaan Resi Gudang apabila akan dibebani dengan hak jaminan seperti melakukan verifikasi Resi Gudang dapat atau tidaknya dibebani hak jaminan, melakukan pemutakhiran status Resi Gudang dan mencatat Pembebanan Hak Jaminan ke dalam buku Daftar Pembebanan Hak Jaminan dan mengirimkan bukti konfirmasi telah diterima dan telah dilakukannya pencatatan pemberitahuan pembebanan Hak Jaminan.

Mengkaji bahwa lahirnya hak kebendaan atas objek jaminan digantungkan pada perwujudan asas publisitas maka dalam UU Resi Gudang lahirnya hak kebendaan diartikan pada saat Penerima Hak Jaminan memberitahukan perjanjian pengikatan Resi Gudang sebagai Hak Jaminan kepada Pusat Registrasi dan Pengelola Gudang. Tujuan pemberitahuan adalah untuk mencegah adanya penjaminan ganda serta memantau peredaran Resi Gudang dan memberikan kepastian hukum tentang pihak yang berhak atas barang dalam hal terjadi wanprestasi. Menandai lahirnya hak kebendaan pada jaminan kebendaan merupakan hal yang sangat penting sekali karena untuk menjamin kepastian hukum atas kedudukan kreditor sebagai kreditor preferen. Perwujudan asas publisitas dalam jaminan kebendaan mempunyai arti penting, yaitu disamping menandai lahirnya hak kebendaan juga memberikan kepastian hukum bagi para pihak dan memberikan perlindungan hukum bagi kreditor maupun pihak ketiga.

Penerima hak oleh UU Resi Gudang diberi kewajiban untuk memberitahukan ke Pusat Registrasi dan Pengelola Gudang adanya pembebanan atas Resi Gudang, apabila kewajiban tersebut tidak dilaksanakan maka mempunyai akibat hukum bagi penerima hak, 
yaitu tidak lahirnya hak kebendaan pada hak jaminan sehingga ciri-ciri unggulan dari hak kebendaan tidak melekat pada penerima hak jaminan. Kedudukan penerima hak jaminan tidak berposisi sebagai kreditor preferen, kedudukan ini jelas sangat merugikan bagi penerima hak, sehingga menjadi suatu pilihan bagi penerima hak untuk berposisi sebagai kreditor preferen atau berposisi sebagai kreditor konkuren.

Adapun tata cara pembebanan dan pemberitahuan hak jaminan adalah sebagai berikut:

Pertama, Calon penerima Hak Jaminan akan menyampaikan permohonan verifikasi Resi Gudang yang akan dibebani Hak Jaminan kepada Pusat Registrasi. Pusat Registrasi melakukan verifikasi: keabsahan Resi Gudang; keabsahan pihak pemberi Hak Jaminan; jangka waktu Resi Gudang; nilai Resi Gudang pada saat diterbitkan; dan telah atau belum dibebaninya Hak Jaminan atas Resi Gudang.

Kepastian dapat atau tidak dapatnya pembebanan Hak Jaminan disampaikan oleh Pusat Registrasi dengan menyampaikan Bukti Konfirmasi melalui SRG-Online dengan menggunakan Model Formulir Nomor SRGOPR.013. Apabila hasil verifikasi menunjukkan bahwa Resi Gudang tidak dapat dijadikan jaminan maka Pusat Registrasi akan memberitahukan kepada calon penerima hak jaminan beserta alasannya. Akan tetapi, apabila dari hasil verifikasi bahwa Resi Gudang dapat diterima sebagai jaminan maka Pusat Registrasi memberitahukan bahwa Resi Gudang tersebut dapat dijaminkan kepada calon penerima hak jaminan. Setelah menerima hasil verifikasi dari Pusat Registrasi maka dilanjutkan dengan penandatangan Perjanjian Pembebanan Hak Jaminan atas Resi Gudang oleh Pemberi dan Penerima Hak Jaminan yang merupakan perjanjian ikutan dari perjanjian pokoknya yaitu perjanjian kredit. Akta perjanjian hak jaminan Resi Gudang sebagaimana diatur pada Pasal 14 UU Resi Gudang sekurang-kurangnya memuat: identitas pihak pemberi dan penerima Hak Jaminan; data perjanjian pokok yang dijamin dengan Hak Jaminan; spesifikasi Resi Gudang yang diagunkan; nilai jaminan utang; dan nilai barang berdasarkan harga pasar pada saat barang dimasukkan ke dalam Gudang.

Kedua, Setelah dilakukan penandatangan maka Penerima Penjaminan harus memberitahukan terjadinya penjaminan Resi Gudang kepada Pusat Registrasi dan Pengelola Gudang dan melampirkan: Bukti Konfirmasi Resi Gudang dapat Dibebani Hak Jaminan dari Pusat Registrasi; fotokopi Perjanjian
Pembebanan Hak Jaminan Atas Resi Gudang; fotokopi Resi Gudang.

Kemudian dari Pusat Registrasi melakukan pemutakhiran status Resi Gudang dan mencatat Pembebanan Hak Jaminan ke dalam buku Daftar Pembebanan Hak Jaminan. Selanjutnya Pusat Registrasi mengirimkan bukti konfirmasi telah diterima dan telah dilakukannya pencatatan pemberitahuan pembebanan Hak Jaminan.

Apabila dibandingkan dengan lembaga jaminan Gadai memang tidak ada pengaturan tentang kewajiban pendaftaran sehingga lahirnya hak kebendaan pada jaminan Gadai, yaitu pada saat benda tersebut diserahkan pada kreditor atau pihak ketiga sebagaimana diatur pada Pasal 1152 (1) BW (Trisadini Prasastinah Usanti, 2012:49). Oleh karena itu, tidak adanya kewajiban pendaftaran pada institusi tertentu maka eksekusi yang terdapat pada lembaga Gadai, yaitu parate eksekusi sebagaimana diatur pada Pasal 1155 BW. Berbeda halnya dengan lembaga jaminan Hipotek, hak tanggungan dan jaminan Fidusia adanya pengaturan tentang pendaftaran pada instansi tertentu untuk melahirkan hak kebendaan, maka konsekuensinya adanya alternatif eksekusi di samping parate eksekusi, yaitu eksekusi dengan titel eksekutorial akibat dari adanya irah-irah yang terdapat pada sertifikat Hipotek, sertifikat hak tanggungan, sertifikat jaminan Fidusia dan eksekusi di bawah tangan.

Berdasarkan karakter dari hak jaminan atas Resi Gudang terdapat satu cara eksekusi, yaitu parate eksekusi sebagaimaa diatur pada Pasal 16 UU Resi Gudang, hal ini sama dengan karakter dari lembaga Gadai. Demikian juga pada lembaga jaminan Gadai, Resi Gudang juga wajib diserahkan atau berada dalam penguasaan kreditor sebagaimana diatur pada penjelasan Pasal 12 ayat (2) UU Resi Gudang. Akan tetapi, berbeda dengan jaminan Gadai bahwa penyerahan benda Gadai pada kreditor atau pihak ketiga menjadi syarat sahnya Gadai sebagaimana diatur pada Pasal 1152 ayat (3) BW, ketentuan ini yang tidak terdapat dalam UU Resi Gudang bahwa kalau Resi Gudang tidak berada di tangan kreditor maka perjanjian jaminannya tidak sah.

Pemberi hak jaminan apabila wanprestasi atau cidera janji maka oleh undang-undang diberikan sarana eksekusi dengan cara parate eksekusi sebagaimana diatur pada Pasal 16 UU Resi Gudang, bahwa:

Pertama, Apabila pemberi Hak Jaminan cidera janji, penerima Hak Jaminan mempunyai hak untuk 
menjual objek jaminan atas kekuasaan sendiri melalui lelang umum atau penjualan langsung.

Kedua, Penerima Hak Jaminan memiliki hak untuk mengambil pelunasan piutangnya atas hasil penjualan sebagaimana dimaksud pada ayat (1) setelah dikurangi biaya penjualan dan biaya pengelolaan.

Ketiga, Penjualan objek jaminan sebagaimana dimaksud pada ayat (1) hanya dapat dilakukan atas sepengetahuan pihak pemberi Hak Jaminan.

Penjualan langsung akan dilakukan dengan mengupayakan harga terbaik yang menguntungkan para pihak. Lembaga parate eksekusi ditujukan agar kreditor mendapat kemudahan pelunasan hak tagihnya. Hal ini merupakan konsekuensi dari konsep lembaga jaminan khusus yang sifatnya memberikan kemudahan dan kedudukan yang didahulukan bagi kreditor dalam mendapatkan pelunasan hak tagihnya. Mengenai parate eksekusi dapat ditinjau pendapat Hoogerrechtssch of van Nerderlands Indie (HGH) yang menyatakan sebagai 'hak untuk mengambil pelunasan tanpa putusan pengadilan'. Jadi seakanakan hak eksekusi selalui siap (paraat) di tangan kreditor. Demikian juga dikemukakan oleh P.A. Stein menyebutkan sebagai 'eksekusi yang disederhanakan'. Keistimewaan dari parate eksekusi terdapat pada dua hal, yaitu: (Teddy Anggoro, 2009:537, 553).

Pertama, Penjualan tanpa melibatkan debitur. Hal ini terkait dengan adanya kuasa mutlak yang tidak dapat ditarik kembali onherroepelijk kepada kreditor, untuk menjual atas kekuasaannya sendiri, yang didapat dengan diperjanjikan dengan tegas (Hipotek) atau karena diberikan oleh undang-undang (Gadai, hak tanggungan dan Fidusia).

Kedua, Penjualan tanpa perantara atau melalui pengadilan. Hal ini terkait dengan kuasa mutlak sebagaimana dijelaskan di atas, dan juga doktrin "eksekusi yang disederhanakan dan murah". Terbayang apabila prosedur penagihan dilakukan melalui/perantara pengadilan (baik dengan prosedur penetapan maupun gugatan) sampai dengan proses sitaan dan eksekusi jelas akan memakan waktu yang lama, belum lagi apabila debitur melakukan verzet-verzetnya. Maka untuk memberikan kepastian pada kreditor dan menegakkan sifat-sifat atau essensilia lembaga jaminan khusus, hal ini sangat logis.

Berdasarkan lampiran-lampiran Peraturan Kepala Badan Pengawasan Perdagangan Berjangka Komoditi Nomor 09/BAPPEBTI/PER-SRG/7/2008 tentang Pedoman Tehnis Penjaminan Resi Gudang tanggal 24 Juli 2008, penjualan objek jaminan diawali dengan melakukan pemberitahuan Penerima Hak Jaminan tentang rencana penjualan objek Hak Jaminan akibat cidera janjinya pemberi Hak Jaminan kepada: pemberi Hak Jaminan, Pusat Registrasi, dan pengelola gudang paling lambat 3 (tiga) hari sebelum pelaksanaan penjualan melalui lelang umum atau paling lambat 3 (tiga) hari sebelum pelaksanaan penjualan langsung. Pemberitahuan paling sedikit memuat: 1 . deskripsi barang meliputi jenis, tingkat mutu, jumlah, dan jika ada kelas barang; 2 . harga yang ditawarkan; dan 3. waktu dan tempat penjualan langsung.

Penerima Hak Jaminan melakukan penjualan objek Hak Jaminan, baik Resi Gudang ataupun barang sebagaimana tercantum dalam Resi Gudang, tanpa memerlukan penetapan pengadilan. Setelah dilakukan penjualan maka Penerima Hak Jaminan memberitahukan kepada Pusat Registrasi tentang penjualan barang atau pengalihan Resi Gudang.

Dalam hal terjadi pengalihan Resi Gudang, Pusat Registrasi akan menyiapkan Rekening Resi Gudang untuk pembeli Resi Gudang dan melakukan pemindahbukuan kepemilikan Resi Gudang. Pusat Registrasi menyampaikan bukti konfirmasi telah dilakukannya pemindahbukuan kepemilikan Resi Gudang dari Rekening Resi Gudang pemberi Hak Jaminan Resi Gudang ke Rekening Resi Gudang pembeli Resi Gudang atau bukti konfirmasi telah dilakukannya pencatatan penjualan barang dalam hal terjadi penjualan barang, kepada penerima Hak Jaminan, pemberi Hak Jaminan, dan Pengelola Gudang.

Dalam hal hasil lelang umum atau penjualan langsung setelah dikurangi biaya penjualan dan biaya pengelolaan tidak mencukupi untuk pelunasan utang, maka pemberi Hak Jaminan tetap bertanggungjawab atas sisa utang yang belum dibayar. Hal ini merupakan konsekuensi dari eksistensi dari perjanjian jaminan sebagai perjanjian tambahan (ikutan), bahwa bilamana perjanjian tambahannya hapus tidak mengakibatkan perjanjian pokoknya hapus, sehingga pemberi hak jaminan tetap berkewajiban untuk melunasi hutangnya kecuali penerima hak jaminan melakukan pembebasan hutang sebagaimana diatur pada Pasal 1381 BW, bahwa salah satu hapusnya perikatan adalah dengan cara pembebasan hutang.

Undang-undang tidak memberikan definisi dari apa yang disebutkan dengan pembebasan utang, yang dimaksud dengan pembebasan utang ialah pembuatan atau pernyataan kehendak dari 
kreditor untuk membebaskan debitur dari perikatan dan pernyataan kehendak tersebut diterima oleh debitur. Menurut Pasal 1439 BW pembebasan utang tidak boleh dipersangkakan tetapi harus dibuktikan (Mariam Darus Badrulzaman, 2001:143).

Hapusnya Hak Jaminan atas Resi Gudang karena hal-hal sebagai berikut: a. hapusnya utang pokok yang dijamin dengan Hak Jaminan dan; b. pelepasan Hak Jaminan oleh penerima Hak Jaminan.

Sesuai dengan sifat ikutan dari perjanjian Hak Jaminan maka keberadaan dari perjanjian Hak Jaminan bergantung pada adanya piutang yang dijamin pelunasannya. Apabila piutang tersebut hapus karena hapusnya utang atau karena pelepasan, dengan sendirinya perjanjian hak jaminan yang bersangkutan menjadi hapus. Dimaksud dengan hapusnya utang, antara lain, karena pelunasan dari Pemegang Resi Gudang atau terjadinya perpindahan kreditor. Bukti hapusnya utang berupa keterangan yang dibuat kreditor. Sedangkan yang dimaksud dengan pelepasan hak jaminan oleh penerima hak jaminan, yaitu dalam hal-hal tertentu, yakni hubungan antara Pemegang Resi Gudang dan kreditor didasari kepercayaan, kreditor merasa tidak perlu lagi memegang hak jaminan dan melepaskan hak jaminan tersebut. Dalam hal ini, kreditor tidak lagi memegang, hak jaminan dan Resi Gudang yang dijaminkan diserahkan kembali kepada Pemegang Resi Gudang. Dalam UU Resi Gudang tidak mengatur bahwa musnahnya objek jaminan sebagai salah satu sebab hapusnya hak jaminan atas Resi Gudang. Padahal sebagaimana diketahui bahwa apabila objek jaminan musnah maka perjanjian jaminannya menjadi hapus. Sebagaimana contoh pengaturan pada Pasal 18 ayat (1d) UUHT bahwa Hak Tanggungan hapus jika hak atas tanah yang dibebani Hak Tanggungan hapus. Demikian juga pada Pasal 25 ayat (1) c UUJF bahwa jaminan Fidusia hapus jika benda yang menjadi objek jaminan Fidusia musnah.

\section{PENUTUP}

\section{Kesimpulan}

Lembaga jaminan kebendaan yang melahirkan hak kebendaan mempunyai ciri-ciri yang sangat istimewa. Adapun ciri pokok dari hak kebendaan antara lain bersifat mutlak, droit de suite, droit de preference, dan mengandung asas prioritas untuk memenuhi sebagai lembaga jaminan kebendaan maka harus terdapat ciri-ciri dari hak kebendaan. Pada hak jaminan Resi Gudang tidak terdapat asas droit de suite sebagai salah satu ciri dari hak kebendaan sebagaimana pada lembaga jaminan Gadai, Hipotek, hak tanggungan dan Fidusia. Demikian juga dengan penentuan lahirnya hak kebendaan pada hak jaminan Resi Gudang tidak secara tegas diatur sehingga ditafsirkan bahwa lahirnya hak kebendaan pada hak jaminan, yaitu pada saat penerima hak jaminan Resi Gudang memberitahukan perjanjian pengikatan Resi Gudang sebagai Hak Jaminan kepada Pusat Registrasi dan Pengelola Gudang. Tujuan pemberitahuan adalah untuk mencegah adanya penjaminan ganda serta memantau peredaran Resi Gudang dan memberikan kepastian hukum tentang pihak yang berhak atas barang dalam hal terjadi wanprestasi. Menandai lahirnya hak kebendaan pada jaminan kebendaan merupakan hal yang sangat penting guna menjamin kepastian hukum atas kedudukan kreditor preferen.

\section{Rekomendasi}

Ketiadaan aturan yang tegas mengenai ciri khas hak jaminan kebendaan yang berupa droit de suite pada jaminan Resi Gudang tentu saja mengakibatkan kedudukan kreditornya tidak cukup terlindungi bilamana Resi Gudang itu jatuh ke tangan selain pemilik atau kreditor. Dalam lembaga jaminan, adanya pendaftaran sejatinya mampu memberikan perlindungan sebagai wujud awal dari ciri droit de Suite. Diluar lembaga jaminan, Resi Gudang sebagai hak kebendaan tentunya juga membutuhkan lembaga pendaftaran yang sifatnya memberikan batasan dalam wujud yang mampu memindahtangankan atau mencairkan Resi Gudang itu hanyalah yang namanya terdaftar. Pendaftaran Resi Gudang sebagai lembaga jaminan juga seyogyanya diperkuat dengan memberikan keterangan dalam dokumen Resi Gudang bahwa Resi Gudang tersebut sedang dijaminkan kepada kreditor tertentu, hal mana seperti lembaga jaminan Hak Tanggungan yang diterapkan pada sertipikat Hak atas Tanahnya. Dengan metode seperti ini maka akan terdapat batasan akan perpindahan Resi Gudang, hal mana memberikan perlindungan yang lebih, bagi kreditor jaminan Resi Gudang atau pemilik Resi Gudang bilamana Resi Gudang itu jatuh ke tangan yang tidak berhak, tidak akan bisa disalahgunakan.

\section{DAFTAR PUSTAKA}

\section{Buku:}

Badrulzaman, Mariam D., et.al. 2001. Kompilasi Hukum Perikatan. Bandung: Citra Aditya Bakti. 
Badrulzaman, Mariam Darus. 2010. Mencari Sistem Hukum Benda Nasional. Bandung:Alumni.

Garner, Bryan A. 2004. Black's Law Dictionary, USA: Eighth Edition, West Publishing Co.

Subekti dan Tjitrosudibio. 2006. Kitab Undang-Undang Hukum Perdata, terjemahan dari Burgerlijk Wetboek. Jakarta: Prandya Paramita.

Sofwan, Sri Soedewi Masjchoen. 1981. Hukum Benda. Jogjakarta: Liberty.

Usanti, Trisadini P. dan Leonora Bakarbessy. 2013. Hukum Jaminan. Surabaya: Revka Petra.

M. Isnaeni. 1996. Hipotek Pesawat Udara. Surabaya: Dharma Muda.

\section{Peraturan Perundang-undangan:}

Undang-Undang Nomor 7 Tahun 1992 tentang Perbankan.

Undang-Undang Nomor 4 Tahun 1996 tentang Hak Tanggungan atas Tanah Beserta Benda-benda yang Berkaitan dengan Tanah.

Undang-Undang Nomor 32 Tahun 1997 tentang Perdagangan Berjangka Komoditi.

Undang-Undang Nomor 10 Tahun 1998 tentang Perubahan Undang-Undang Nomor 7 Tahun 1992 tentang Perbankan.

Undang-Undang Nomor 42 Tahun 1999 tentang Jaminan Fidusia.

Undang-Undang Nomor 9 Tahun 2006 tentang Sistem Resi Gudang.
Undang-Undang Nomor 9 Tahun 2011 tentang Perubahan Undang-Undang Nomor 9 Tahun 2006 tentang Sistem Resi Gudang.

Peraturan Pemerintah Nomor 36 Tahun 2007 tentang Pelaksanaan Undang-Undang Nomor 9 Tahun 2006 tentang Sistem Resi Gudang.

Peraturan Bank Indonesia Nomor 14/5/PBI/2012 tentang Penilaian Kualitas Aset Bank Umum.

Peraturan Kepala Badan Pengawasan Perdagangan Berjangka Komoditi Nomor 09/BAPPEBTI/PERSRG/7/2008 tentang Pedoman Tehnis Penjaminan Resi Gudang tanggal 24 Juli 2008.

Peraturan Menteri Perdagangan RI Nomor 26/MDAG/PER/6/2007 tentang Barang yang dapat Disimpan di Gudang dalam Penyelenggaraan Sistem Resi Gudang.

\section{Jurnal:}

Anggoro, Teddy. 2009. "Parate Eksekusi: Hak Kreditor yang Menderogasi Hukum Formil (Suatu Pemahaman Dasar dan Mendalam)", Jurnal Hukum dan Pembangunan, Tahun ke-3, Nomor 4.

Hasan, Djuhaendah. 2000. "Aspek Hukum Jaminan Kebendaan dan Perorangan”, Jurnal Hukum Bisnis, Volume 11.

Usanti, Trisadini Prasastinah. 2012. "Lahirnya Hak Kebendaan", Jurnal Perspektif Hukum, Fakultas Hukum UWKS, Volume 17, Nomor 1. 